\title{
Negative and positive aspects of the presence of Canadian goldenrod in the environment
}

* Siedlce University of Natural Sciences and Humanities, Faculty of Exact and Natural Sciences, Siedlce, Poland; e-mail: elzbieta.krolak@uph.edu.pl

\section{Keywords:}

Solidago canadensis, invasive plant, phytoremediation properties, energy plant, algicide, honey plant, antibacterial properties, herbal plant

\begin{abstract}
Canadian goldenrod (Solidago canadensis L.) is classified as an invasive plant species in many Eurasian countries. The species shows a great ability to environmentally spread in a variety of habitats, anthropogenic ones included. Based on the literature data, the paper discusses the negative effects of the presence of $S$. canadensis in the environment, including the reduction of biodiversity in plants and some species of insects and insectivorous birds. The occurrence of goldenrod clusters also contributes to soil degradation. Positive aspects related to the presence of $S$. canadensis are also discussed in the paper. Goldenrod can be used in the phytoremediation of soils contaminated with heavy metals and as an energy plant. Its extracts are effective in controlling the bloom of some algae in water reservoirs and in fighting fungal and bacterial diseases in plants. Goldenrod inflorescences' abounding nectar allows for the efficient harvesting of honey. Both the inflorescences and the leaves of the plant are a valuable herbal raw material with a wide spectrum of activity, including its impact on gram-positive and gram-negative bacteria and yeasts. For these reasons, goldenrod deserves special attention in environmental research.
\end{abstract}

c) IOŚ-PIB

\section{INTRODUCTION}

Anthropogenic transformations of the environment in the last few decades have resulted in ecological problems, including invasions of alien plant species. Invasive plant species are entering new territories in great numbers. Their presence is most often the result of conscious or accidental human transfer of diaspores [Tokarska-Guzik et al. 2012]. The greater the human activity and the related transformations of the natural environment are, the more invasive species appear in ecosystems [Chytry et al. 2009]. Successful invasions of plants depend not only on the plants' biological features and their life strategies but also on the environmental characteristics of the invaded areas and the biological interactions with native organisms [Ehrenfeld 2010; Lanta, Norrdahl 2018]. Invasive plants are most often characterised by rapid growth and intensive reproduction. Their diaspores can be transported over long distances [Myers et al. 2004; Moravcová et al. 2010]. Invasive plants can strongly modify the properties of an ecosystem they inhabit [Eppinga, Molofsky 2013; Sardans et al. 2017]. The degree of ecosystem modification under the influence of invasive plants depends on the species and the place. The high competitive ability of many invasive species reduces the biodiversity of native phytocoenoses [Gioria, Osborne 2014]. Invasive plants can also contribute to soil degradation, which is greater in habitats with low nutrient abundance than in environments richer in nutrients [Sardens et al. 2017].

Numerous studies on the impact of invasive plant species focus on the negative impact of alien plants on native phytocoenoses [Tokarska-Guzik et al. 2012] (e.g. threatening biodiversity and functioning of ecosystems). Positive effects of the presence of invasive alien plants are rarely noted. This paper, based on the literature data and on our own research, discusses both the negative and positive aspects of the occurrence of Canadian goldenrod.

\section{CHARACTERISTICS OF CANADIAN GOLDENROD (SOLIDAGO CANADENSIS L.)}

Canadian goldenrod, like the late goldenrod (Solidago gigantea Aiton) and the narrow-leaved goldenrod (Solidago graminifolia (L.) Elliott), is considered an invasive domestic species in Poland [Tokarka-Guzik et al. 2012]. These species represent the genus Solidago spp. (Asteraceae). Most species of goldenrod come from North America [Weber, Schmid 1998]. In the last century, species representing the genus Solidago have spread throughout almost all of Europe [Weber 2000] and Asia [Weber et al. 2008; Semple, Rao 2017]. They are also recorded in Africa 
[Cheek, Semple 2016] and Australia [Semple, Uesugi 2017; Semple et al. 2017]. They occupy increasingly larger areas in newly invaded habitats [Weber, Schmidt 1998; TokarskaGuzik et al. 2012].

Among the species of goldenrod occurring in Poland, Canadian goldenrod Solidago canadensis, which was first noted in 1872 [Tokarska-Guzik et al. 2012], deserves special attention. S. canadensis is a perennial plant with a high reproductive ability. The species reproduces generatively and vegetatively [Weber 2000]. Individual shoots produce more than 10,000 seeds, which are easily blown by the wind over long distances. This facilitates the colonisation of new areas at distances far from the parent population [Gassman, Weber 2005]. In new habitats, Solidago usually reaches a greater biomass of the aboveground parts than native species [Zhang et al. 2009]. Goldenrod is a species that penetrates into not only natural [TokarskaGuzik et al. 2012] and semi-natural (partially transformed) communities but also into plant communities growing in anthropogenic habitats. S. canadensis has a high seed germination rate; under favourable conditions, it reaches the value of $80 \%$ [Szymura 2012]. The species is also characterised by a great ability to spread its underground parts: roots and rhizomes. The roots extend to the base of the ramet and reach a minimum depth of $20 \mathrm{~cm}$. Each rhizome can produce a single aboveground stem [Weber 2000]. Individual clones form dense clusters composed of many ramets, depending on the age of the clone. Therefore, in places of its occurrence, especially in anthropogenic habitats, Canadian goldenrod forms extensive and compact fields [Szymura, Wolski 2006]. S. canadensis is characterised by high tolerance to chemical changes in the substrate [Mei et al. 2006; Huang et al. 2007; Priede 2008], such as changes in soil pH, minerals and organic matter. It prefers moist habitats in river valleys, forests, shrubs and meadows [Dajdok, Pawlaczyk 2009]. It also grows massively in fields excluded from agricultural cultivation [Rola, Rola 2010]. It occurs on roadsides, on embankments [Dajdok, Pawlaczyk 2009] and in balks [Szymura, Wolski 2006]. It also overgrows green belts in cities [Guo, Fang 2003]. The species tolerates high levels of metals in the soil [Yang et al. 2008; Nowińska et al. 2012], as evidenced by the presence of the plant in sites near pollutants [Rostański 1997], industrial waste dumps [Rostański 2006], post-industrial wastelands [Antonijević et al. 2012; Nowińska et al. 2012; Patrzałek et al. 2012] and municipal waste landfills [Dyguś 2013]. According to Wang et al. (2021), an important factor in the success of $S$. canadensis invasion may be its larger height compared to native species, which can enable it to obtain greater competitiveness for sunlight acquisition.

\section{NEGATIVE ASPECTS OF THE PRESENCE OF CANADIAN GOLDENROD IN THE ENVIRONMENT}

A wide spectrum of habitat conditions, ease of reproduction and entering new areas, and the high competitive ability of S. canadensis lead to its domination in the structures of plant communities. This species has allelopathic effects on co-occurring species. It produces secondary metabolites that are released into the environment by roots and rhizomes and may be the reason for the success of the plant's invasion [Sun et al. 2006; Abhilasha et al. 2008; Yuan et al. 2013]. In places dominated by S. canadensis, reduction in plant species diversity can be as high as $60 \%$ [de Groot et al. 2007]. This is especially true of annual species and perennials [Bielecka et al. 2020]. The invasion of goldenrod as a species alien to the native flora is favoured by external factors, such as fragmentation of ecosystems and abandonment of arable land cultivation, as well as modification or degradation of habitats.

The presence of goldenrod, mainly before the flowering period, adversely affects the abundance of insect communities, including wild bees, hoverflies, moths and some ground beetles [de Groot et al. 2007; Moroń et al. 2009; Fenesi et al. 2015]. Insect species, which are narrow food specialists, are particularly exposed to the presence of invasive plant species such as goldenrod [de Groot et al. 2007]. Goldenrod reduces the size of the ant colonies but increases the range of foraging ants; in the goldenrod habitat, worker ants travel greater distances from their mother colony in search of food [Lenda et al. 2013]. In the habitats occupied by goldenrod, there is a decrease in the diversity of bird species and the number of breeding pairs associated with meadow habitats [Skórka et al. 2010]. These changes especially affect insectivorous birds [Tryjanowski et al. 2011].

Invasive plant species can also modify the $\mathrm{C}$ and $\mathrm{N}$ cycles in the soil [Ehrenfeld 2010]. The presence of goldenrod causes an increase in the organic carbon content in the soil, but it does not significantly affect the nitrogen content. As a result, it causes an increase in the soil's $\mathrm{C} / \mathrm{N}$ ratio compared to the control sites [Vanderhoeven et al. 2006; Bielecka et al. 2020]; an increase in the $\mathrm{C} / \mathrm{N}$ value in the soil is one of the symptoms of soil degradation [Baran, Turski 1996].

The presence of $S$. canadensis in the environment may contribute to the formation of new taxa; in Europe, the formation of the Solidago $\times$ Niederederi hybrid, which arises from the crossing of goldenrod $S$. canadensis with goldenrod S. virgaurea, has been reported. It occurs in anthropogenic habitats together with both parental species, and its presence attests to the invasive character of S. canadensis [Pliszko, Zalewska-Gałosz 2016].

S. canadensis is considered a species that is not easy to control chemically, as shown by its resistance to some herbicides (e.g., Glean 75 WG, Fernando 225EC, Aminopielik D $450 \mathrm{SL}$ ). The above-mentioned herbicides used during the growth of S. canadensis (12-14 leaf phase) caused a loss of several percent in the fresh weight of the aboveground parts of the plant. The use of Roundup Ultra $360 \mathrm{SL}$ reduced the fresh mass of the plant by about $60 \%$ [Rzymowska et al. 2015]. Similar results were obtained in China, where plant regrowth was also observed after the application of herbicides containing glyphosate, bentazone and oxyfluorfen [Shen et al. 2005]. 


\section{POSITIVE ASPECTS OF THE PRESENCE OF CANADIAN GOLDENROD IN THE ENVIRONMENT}

The high tolerance of $S$. canadensis to soil contaminated with heavy metals and the accumulation of selected metals in the aboveground and underground parts of the plant can be used in the phytoremediation of contaminated soils. In polluted soils, the plant shows a particular tendency to accumulate $\mathrm{Pb}$ [Yang et al. 2008; Xiang et al. 2010; Antonijević et al. 2012; Bielecka, Królak 2019a], Cd [Dąbrowska et al. 2017], Hg [Tomiyasu et al. 2005] and Cu [Antonijević et al. 2012; Bielecka, Królak 2019b] in its underground parts. Research carried out in the vicinity of Olkusz, Poland (a region particularly contaminated with $\mathrm{Pb}$ and $\mathrm{Zn}$ ), showed that $\mathrm{S}$. canadensis accumulates, on average, $520 \mathrm{~g} \mathrm{~Pb} / \mathrm{ha}$ (maximum about 3,500 g Pb/ha) and about $450 \mathrm{~g} \mathrm{Zn/ha} \mathrm{(max.} \mathrm{2,500} \mathrm{g/ha)} \mathrm{in} \mathrm{its} \mathrm{underground}$ parts [Bielecka, Królak 2019a]. Therefore, it can act as a phytostabiliser for these metals. It is predisposed to the task by an extensive system of underground organs (roots and rhizomes) [Bielecka, Królak 2019c]. In addition, an extensive system of roots and rhizomes allows for the stabilisation of the substrate and protects against erosion. This is especially important in the case of goldenrod presence in landfills abundant in fine-grained fractions rich in heavy metals.

The plant also has a tendency to transform some metals, such as Zn [Dąbrowska et al. 2017; Bielecka, Królak 2019a] and Mn [Antonijević et al. 2012; Bielecka, Królak 2019b], in its aboveground parts. For example, Canadian goldenrod in the Olkusz area accumulates, on average, about $470 \mathrm{~g}$ $\mathrm{Zn} / \mathrm{ha}$ (max. about 3,300 g/ha) in its aboveground parts. For comparison, $\mathrm{Zn}$ accumulation in other plant species (Sorghum biocolor, Helianthus annuus, Brassica Juncewa, Medicago sativa, Zea mays) used in phytoremediation of soils contaminated with this metal is $410 \mathrm{~g} / \mathrm{ha}$ ( $H$. annuus) to $1,410 \mathrm{~g} / \mathrm{ha}$ (S. biocolor) [Zhuang et al. 2009]. The plant's ability to accumulate selected metals in its aboveground parts (stems, leaves) can be used in phytoextraction processes in contaminated soils. Klimont (2004) and Klimont et al. (2013) indicate the usefulness of goldenrod in the recultivation of soil degraded by industry. For example, the presence of goldenrod with the addition of municipal sewage sludge in areas of sulphur exploitation improves the chemical properties of the substrate and accelerates the biological regeneration processes of degraded areas [Klimont et al. 2013].

The high biomass of the goldenrod's aboveground parts is also noteworthy. With a plant density of about 120 plants $/ \mathrm{m}^{2}$, it reaches a biomass of 15.9 tonnes of $\mathrm{d} . \mathrm{m} . / \mathrm{ha}$ [Ciesielczuk et al. 2014]. The value is comparable to the biomass of other plant species used in phytoremediation, e.g., Miscantus $x$ giganteus (miscanthus) or Sida hermaphrodita (mallow) [Kabała et al. 2010]. An important property of S. canadensis is its high calorific value, estimated at about 19.3 MJ/kg d.m. [Patrzałek et al. 2012]. The calorific value of S. canadensis is comparable to the calorific value of straw, estimated at 13.5-19.0 MJ/kg d.m. [Denisiuk 2009]. Due to the high biomass of the aboveground parts and the high calorific value of goldenrod, the possibility of using the plant for energy purposes is indicated [e.g., Biskupski et al. 2012; Patrzałek et al. 2012].

Studies conducted in the last decade showed that $S$. canadensis extracts can significantly inhibit the growth of cyanobacteria in surface waters [Huang et al. 2013, 2014]. The authors indicate the use of $S$. canadensis as an algicide to control Microcystis blooms. Their presence is noted in eutrophic and hypertrophic lakes [Błaszczyk et al. 2010].

The essential oils obtained from S. canadensis can be used to combat some common plant diseases caused by certain phytopathogenic fungi (e.g., Monilinia fructicola, Botrytis cinerea, Aspergillus niger and Penicillium expansum). They also show antibacterial activity against Bacillus megaterium, Clavibacter michiganensis (G+ve), Xanthomonas campestris, Pseudomonas fluorescens and Pseudomonas syringae pv. phaseolicola (G-ve) and therefore can be used in plant protection [Elshafie et al. 2016, 2019]. The essential oils obtained from the leaves of $S$. canadensis are also toxic to Culex quinquefasciatus and Spodoptera littoralis third-instar larvae and Musca domestica adult females [Benelli et al. 2019].

The goldenrod flowering period (late summer and early autumn) is valuable for some insects. During this period, predatory and parasitic organisms such as hoverflies but also other pollinators (e.g., the honey bee Apis mellifera [Hurej et al. 2012]) feed on S. canadensis pollen and nectar. Jachuła et al. (2019) report that during the flowering period of Solidago, as many as $80 \%$ of insects visiting plant inflorescences are the honey bee Apis mellifera. $S$. canadensis is considered to be one of the most important honey plants in Central Europe. It blooms in the period when the possibility of bees obtaining honey (nectar, pollen) from other species of honey plants is limited [Amtmann 2010]. The mass of S. canadensis inflorescences during the intensive flowering period is over $20 \%$ of the biomass of the aboveground parts of the plant [Bielecka and Królak 2019c]. Due to the formation of dense populations and the massive flower exposure, the plant produces large amounts of nectar. It is estimated that under favourable conditions, goldenrod inflorescences in an area of 1 ha can deliver up to $800 \mathrm{~kg}$ of honey [Jabłoński et al. 1992], and S. canadensis is characterised by the highest honey yield among plant species [Lipiński 2010]. Among the honeys available in the Polish market, goldenrod honey has the highest antibiotic activity [Kędzia et al. 2014] and the highest content of organic acids [Sowa et al. 2016], the presence of which extends the expiration of honey [Suarez-Luque et al. 2002]. Goldenrod honey has anti-inflammatory, diuretic and choleretic effects. It is used to treat urolithiasis, inflammation of the urinary system, hypertension, edema, disorders in urination and bile secretion [Różański et al. 2016].

Herba Solidaginis, the herb of goldenrod, containing leaves and inflorescences of the plant, has also been 
used in medicine. The composition of biologically active substances contained in the raw herbal material and the use of Solidago in modern phytotherapy have been described in Kołodziej et al. (2011), Šutovská et al. (2013) and Różański et al. (2016). The authors report that the substances contained in goldenrod help in the treatment of inflammations and infections of the urinary and sexual system, urolithiasis, inflammation and respiratory infections, hypertension, metabolic disorders, diabetes, rheumatic diseases, and metabolic skin diseases. The essential oil extracted from S. canadensis inflorescence contains active compounds with selective activity on gram-positive and gram-negative bacterial and yeast species and interferes with microbial adhesion [Marinas et al. 2020]. Therefore, goldenrod extracts are used in many medicines, and the raw material is a component of various herbal mixtures applied in phytotherapy. Różański et al. (2016) recommend to make infusions of Solidago flowers or leaves. The low accumulation of heavy metals, such as $\mathrm{Pb}$ and $\mathrm{Zn}$ in the inflorescences, compared to other morphological parts of S. canadensis is noteworthy [Bielecka et al. 2019a]. Metals particularly toxic to a human organism $(\mathrm{Pb}, \mathrm{Cd}, \mathrm{Hg})$ mainly accumulate in the underground parts of the plant.

\section{SUMMARY}

Like other invasive species, S. canadensis shows a rapid growth rate in new habitats, reaches a high biomass of its aboveground parts, degrades habitats and poses a threat to biodiversity. Methods ensuring the almost complete elimination of invasive species of goldenrod from the environment have been described by Kopeć and Michalska-Hejduk (2016).

The presence of S. canadensis in the environment should definitely be kept under control. The easiest way to reduce the infestation of goldenrod is by limiting the spread of its seeds. An effective solution may be cutting plants during the intensive flowering period, before the seeds are fully mature. Material obtained in this way can be used in various ways: as a herbal raw material, an energy raw material, a substrate for the extraction of valuable ingredients used in the fight against fungal and bacterial diseases of plants and in the fight against some algae bloom in water reservoirs.

\section{ACKNOWLEDGEMENTS}

I am grateful to anonymous Reviewers whose remarks and suggestions improved the quality of this paper.

\section{REFERENCES AND LEGAL ACTS}

ABHILASHA D., QUINTANA N., VIVANCO J., JOSHI J. 2008. Do allelopathic compounds in invasive Solidago canadensis s.I. restrain the native European flora? Journal of Ecology, 96: 993-1001.

AMTMANN M. 2010. The chemical relationship between the scent features of goldenrod (Solidago canadensis L.) flower and its unifloral honey. Journal of Food Composition and Analysis, 23: 122-129.

ANTONIJEVIĆ M. M., DIMITRIJEVIĆ M. D., MILIĆ S. M., NUJKI M. M. 2012. Metal concentrations in the soils and native plants surrounding the old flotation tailings pond of the copper mining and smelting complex Bor (Serbia). Journal of Environmental Monitoring, 14: 866-877.

BARAN S., TURSKI R. 1996. Degradacja, ochrona i rekultywacja gleb [Degradation, conservation and reclamation of soil]. Wydawnictwa Akademii Rolniczej w Lublinie.

BENELLI G., PAVELA R., CIANFAGLIONE K., NAGY D. U., CANALE A., MAGGI F. 2019. Evaluation of two invasive plant invaders in Europe (Solidago canadensis and Solidago gigantea) as possible sources of botanical insecticides. Journal of Pest Science, 92(2): 805-821.

BIELECKA A., KRÓLAK E. 2019a. Solidago canadensis as a bioaccumulator and phytoremediator of $\mathrm{Pb}$ and $\mathrm{Zn}$. Environmental Science and Pollution Research, 26: 3694236951.

BIELECKA A., KRÓLAKE. 2019b. The accumulation of Mn and $\mathrm{Cu}$ in the morphological parts of Solidago canadensis under different soil conditions. PeerJ, 7: e8175.
BIELECKA A., KRÓLAK E. 2019c. Selected features of Canadian goldenrod that predispose the plant to phytoremediation. Journal of Ecological Engineering, 20(10): 88-93.

BIELECKA A., BORKOWSKA L., KRÓLAK E. 2020. Environmental changes caused by the clonal invasive plant Solidago canadensis. Annales Botanici Fennici, 57: 33-48.

BISKUPSKI A., ROLA J., SEKUTOWSKI T., KAUS A., WŁODEK S. 2012. Wstępne wyniki dotyczące technologii zbioru biomasy Solidago sp. i jej przetwarzania do celów opałowych [Preliminary study on the harvest technology of biomass Solidago sp. and its processing for combustible purposes]. Zeszyty Naukowe Uniwersytetu Przyrodniczego we Wrocławiu, 584: 7-15.

BŁASZCZYK A., TORUŃSKA A., KOBOS J., BROWARCZYKMATUSIAK G., MAZUR-MARZEC H. 2010. Ekologia toksycznych sinic [Ecology of toxic cyanobacteria]. Kosmos. Problemy Nauk Biologicznych, 59(1-2): 173198.

CHEEK M. D., SEMPLE J. C. 2016. First official record of naturalised populations of Solidago altissima L. var. pluricephala M. C. Johnst. (Asteraceae: Astereae) in Africa. South African Journal of Botany, 105: 333-336.

CHYTRÝ M., PYŠEK P., WILD J., MASKELL L. C., PINO J., VILÀ M. 2009. European map of alien plant invasions, based on the quantitative assessment across habitats. Diversity and Distributions 15: 98-107. 
CIESIELCZUK T., POLUSZYŃSKA J., SPOREK M. 2014. Potential uses for solid biofuels from non-food crops. Proceedings of ECOpole, 8(2): 363-368.

DAJDOK Z., PAWLACZYK P. (red.) 2009. Inwazyjne gatunki ekosystemów mokradłowych Polski [Invasive species of Polish wetland ecosystems]. Wyd. Klubu Przyrodników, Świebodzin.

DĄBROWSKA D., STRZELCZYK Ł., JĘDRZEJCZYKKORYCIŃSKA M., ROSTAŃSKI A. 2017. Wpływ wybranych czynników abiotycznych na kumulację metali ciężkich przez nawłoć kanadyjską (Solidago canadensis L.) [Effect of abiotic factors on accumulation of heavy metals by Canadian Goldenrod (Solidago canadensis L.)], In SIERKA E., NADGÓRSKA-SOCHA A. "Aktualne Problemy Ochrony Środowiska. Ocena Stanu, Zagrożenia Zasobów i Stosowane Technologie" ("Current Problems of Environmental Protection. [The state, assessment, resource threats and applied technologies"] (pp. 68-69). Wydawnictwo Uniwersytetu Śląskiego, Katowice.

DENISIUK W. 2009. Słoma jako paliwo [Straw as fuel]. Inżynieria Rolnicza 1(110): 83-89.

DE GROOT M., KLEIJN D., JOGAN N. 2007: Species groups occupying different trophic levels respond differently to the invasion of semi-natural vegetation by Solidago Canadensis. Biological conservation, 136: 612-617.

DYGUŚ K. H. 2013. Roślinność dwóch składowisk odpadów komunalnych Mazowsza [Vegetation of two municipal waste landfills of Mazovia]. Inżynieria Ekologiczna, 34: 96-120.

EHRENFELD J.G. 2010: Ecosystem consequences of biological invasions. Annual Review of Ecology, Evolution and Systematics, 41: 59-80.

ELSHAFIE H. S., SAKR S., MANG S. M., DE FEO V., CAMELE I. 2016. Antimicrobial activity and chemical composition of three essential oils extracted from Mediterranean aromatic plants. Journal of Medicinal Food, 19: 10961103.

ELSHAFIE H. S., GRUL'OVÁ D., BARANOVÁ B., CAPUTO L., De MARTINO L., SEDLÁK, V., CAMELE I., DE FEO V. (2019). Antimicrobial activity and chemical composition of essential oil extracted from Solidago canadensis L. growing wild in Slovakia. Molecules, 2, 1-13.

EPPINGA M.B., MOLOFSKY J. 2013. Eco-evolutionary litter feedback as a driver of exotic plant invasion. Perspectives in Plant Ecology, Evolution and Systematics, 15: 20-31.

FENESI A., VÁGÁSI C.I., BELDEAN M., FÖLDESI R., KOLCSÁR L. P., SHAPIRO J. T. 2015. Solidago canadensis impacts on native plant and pollinator communities in differentaged old fields. Basic and Applied Ecology, 16: 335-346.

GASSMAN A., WEBER E. 2005. Solidago canadensis. In WITTENBERG R. (ed.), An Inventory of Alien Species and Their Threat to Biodiversity and Economy in Switzerland" (pp. 413-414). CABI Bioscience Switzerland Centre report to the Swiss Agency for Environment, Forests and Landscape. Delemon.

GIORIA M., OSBORNE B. A. 2014. Resource competition in plant invasions: emerging patterns and research needs. Frontiers in Plant Science, 5: 501-521.
GUO S. L., FANG F. 2003. Physiological adaptation of the invasive plant Solidago canadensis to environments. Acta Physica Sinica, 27(1): 47-52.

HUANG H., GUO S., CHEN G. 2007. Reproductive biology in an invasive plant. Solidago canadensis. Frontiers in Biology, 2(2): 196-204.

HUANG Y., BAI Y., WANG Y., KONG H. 2013. Allelopathic effects of the extracts from an invasive species Solidago canadensis L. on Microcystis aeruginosa. Letters in Applied Microbiology, 57: 451-458.

HUANG C., WANG X., YANG H., LI Y., WANG Y., CHEN X., XU L. 2014. Satellite data regarding the eutrophication response to human activities in the plateau lake Dianchi in China from 1974 to 2009. Science of the Total Environment, 485(1): 1e11.

HUREJ M., TWARDOWSKI J., ŁUKOWIAK D., WILCZYŃSKA K. 2012. Beneficial arthropods visiting Canada goldenrod (Solidago canadensis L.) in selected habitats in Wrocław area. Progress In Plant Protection, 52(2): 335-339.

JABŁOŃSKI $\quad$ B., KOTŁOWSKI Z., DĘBSKA B. 1992. Nektarowanie i wydajność miodowa ważniejszych roślin miododajnych w warunkach Polski [Nectar secretion and honey efficiency of important honey plants growing under Poland's conditions]. Pszczelnicze Zeszyty Naukowe, 36: 54-64.

JACHUŁA J., DENISOW B., STRZAŁKOWSKA-ABRAMEK M. 2019. Floral reward and insect visitors in six ornamental Lonicera species - plants suitable for urban bee-friendly gardens. Urban Forestry \& Urban Greening, 44: 126390.

KABAŁA C., KARCZEWSKA A., KOZAK M. 2010. Przydatność roślin energetycznych do rekultywacji i zagospodarowania gleb zdegradowanych [Energetic plants in reclamation and management of degraded soils]. Zeszyty Naukowe Uniwersytetu Przyrodniczego we Wrocławiu, Rolnictwo, 576: 97-118.

KĘDZIA B., HOŁDERNA-KĘDZIA E., DUTKOWIAK A. 2014 Aktywność antybiotyczna krajowych miodów odmianowych [The antibiotic activity of Polish monofloral honeys].

Postępy Fitoterapii, 2: 67-70.

KLIMONT K. 2004. Przydatność wybranych gatunków roślin użytkowych do rekultywacji terenów zdewastowanych [Application of some useful plants in soil reclamation]. Zeszyty Problemowe Postępów Nauk Rolniczych, 497: 673-684.

KLIMONT K., BULIŃSKA-RADOMSKA Z., GÓRKA J. 2013. Możliwość wykorzystania wybranych roślin miododajnych do rekultywacji terenów po eksploatacji siarki [Utilization possibility of selected honeybee plants for land reclamation of sulphur post-exploitation area]. Polish Journal of Agronomy, 12: 17-25.

KOŁODZIEJ B., KOWALSKI R., KĘDZIA B. 2011. Antibacterial and antimutagenic activity of extracts aboveground parts of three Solidago species: Solidago virgaurea L., Solidago canadensis L. and Solidago gigantea Ait. Journal of Medicinal Plants Research, 5(31): 6770-6779.

KOPEĆ D., MICHALSKA-HEJDUK. 2016. Gatunki z rodzaju nawłoć Solidago spp. [Goldenrod species Solidago 
spp]. W OBIDZIŃSKI A., KOŁACZKOWSKA E., OTRĘBY A. (red.) Metody zwalczania obcych gatunków roślin występujących na terenie Puszczy Kampinoskiej [Methods of combating foreign plant species occurring in the Kampinos Forest]. Kampinoski Park Narodowy, Izabelin, 51-58.

LANTA V., NORRDAHL K. 2018. Differing germination success may explain lower species richness of herbaceous vegetation below non-native than native shrubs. Annales Botanici Fennici, 55: 7-15.

LENDA M, WITEK M, SKÓRKA P, MOROŃ D, WOYCIECHOWSKI M. 2013. Invasive alien plants affect grassland ant communities, colony size and foraging behaviour. Biological Invasions, 15(11): 2403-2414.

LIPIŃSKI M. 2010. Pożytki pszczele [Bee benefits], Państwowe Wydawnictwo Rolnicze i Leśne, Warszawa.

MARINAS I. C., OPREA E., BULEANDRA M., BLEOTU C., BADERA I. A., ANASTASIU P., LAZAR V., GARDUS I. D., CHIFIURIUC M. C. 2020. Chemical, Antimicrobial, Antioxidant and Anti-proliferative Features of the Essential Oil Extracted from the Invasive Plant Solidago canadensis L. Revista de Chimie, 71(7): 255-264.

MEI D., WENJU Z., JIAKUAN C. B. L. 2006. Canada goldenrod (Solidago canadensis): an invasive alien weed rapidly spreading in China. Acta Phytotaxonomica Sinica, 44: 72-85. MORAVCOVÁ L., PYŠEK P., JAROŠIK V., HAVLIČKOVÁ V., ZÁKRAVSKY P. 2010. Reproductive characteristics of neophytes in the Czech Republic: traits of invasive and non-invasive species. Preslia, 82: 365-390.

MOROŃ D., LENDA M., SKÓRKA P., SZENTGYÖRGYI H., SETTLE J., WOYCIECHOWSKI M. 2009. Wild pollinator communities are negatively affected by invasion of alien goldenrods in grassland landscapes. Biological Conservation, 142: 1322-1332.

MYERS J. A., VELLEND M., GARESCU S., MARKS P. L. 2004. Seed dispersal by white-tailed deer: implications for long-distance dispersal, invasion, and migration of plants in eastern North America. Oecologia, 139: 35-44.

NOWIŃSKA K., KOKOWSKA-PAWŁOWSKA M., PATRZAŁEK A. 2012. Metale w Calamagrostis epigejos i Solidago sp. ze zrekultywowanych nieużytków poprzemysłowych [Metals in Calamagrostis epigejos and Solidago sp. from reclaimed post-industrial wastelands]. Infrastruktura $i$ Ekologia Terenów Wiejskich, 3(3): 91-100.

PATRZAŁEK A., NOWIŃSKA K., KOKOWSKA-PAWŁOWSKA M. 2012. Nawłoć - Solidago sp. w siedliskach trudnych jako potencjalna roślina energetyczna [Goldenrod - Solidago $\mathrm{sp}$. in hard sites as potential energetic plant]. Zeszyty Naukowe Uniwersytetu Przyrodniczego we Wrocławiu. Rolnictwo C, 585: 51-61.

PLISZKO A., ZALEWSKA-GAŁOSZ J. 2016. Molecular evidence for hybridization between invasive. Solidago canadensis and native S. virgaurea. Biological Invasions 18: 3103-3108.

PRIEDE A. 2008. Invasive non-native Solidago species in Latvia: expansion history and current distribution. Proceedings of the Latvian Academy of Sciences, Section B, 62: 78-83.
ROLA J., ROLA H. 2010. Solidago spp. biowskaźnikiem występowania odłogów na gruntach rolnych [Solidago spp. as bioindicator of fallow occurrence on arable area]. Fragmenta Agronomica, 27(3): 122-131.

ROSTAŃSKI A. 1997. Zawartość metali ciężkich w glebie i roślinach z otoczenia niektórych emiterów zanieczyszczeń na Górnym Śląsku [The content of heavy metals in soil and plants from the vicinity of some pollutants in Upper Silesia]. Archiwum Ochrony Środowiska, 23(3-4): 181-189.

ROSTAŃSKI A. 2006. Spontaniczne kształtowanie się pokrywy roślinnej na zwałowiskach po górnictwie węgla kamiennego na Górnym Śląsku [Spontaneous formation of the vegetation cover on the dumps after hard coal mining in Upper Silesia]. Prace Naukowe Uniwersytetu Śląskiego w Katowicach 2410: 1-232.

RÓŻAŃSKI H., BOBAK Ł., TRZISZKA T. 2016. Znaczenie nawłoci (Solidago) w fitoterapii [Meaning of goldenrod (Solidago) in phytotherapy]. Herbalism, 1(2): 160-173.

RZYMOWSKA Z., SKRZYCZYŃSKA J., WYRZYKOWSKA M. 2015. Ocena skuteczności wybranych herbicydów do zwalczania Solidago canadensis L. [Assessment of selected herbicides applied to suppress Solidago canadensis L.] Zeszyty Naukowe Uniwersytetu Przyrodniczo-Humanistycznego w Siedlcach, Seria Rolnictwo, 2(2): 15-24.

SARDANS J., BARTRONS M., MARGALEF O., GARGALLOGARRIGA A., JANSSENS I. A., CIAIS P., OBERSTEINER M., SIGURDSSON B. D., CHEN H. Y. H., PEŇUELAS J. 2017. Plant invasion is associated with higher plant-soil nutrient concentrations in nutrient-poor environments. Global Change Biology 23: 1282-1291.

SEMPLE J. C., RAO K. S. 2017. Solidago altissima var. pluricephala (Asteraceae: Astereae) in India. Phytoneuron, 32: 1-6.

SEMPLE J. C., UESUGI A. 2017 Solidago altissima var. pluricephala (Asteraceae: Astereae) in Australia, Tonga, and Hawaii. Phytoneuron, 40: 1-16.

SEMPLE J. C., Laphitz R. L., Uesugi A., Coffey S.C., Walsh N.G. 2017. Multivariate morphometric confirmation of Solidago chilensis (Asteraceae: Astereae) in Australia. Phytoneuron, 42: 1-10.

SHEN G. H., YAO H. M., GUAN L. Q., QIAN Z. G., AO Y. S. 2005. Distribution and Infestation of Solidago canadensis L. in Shanghai Suburbs and its Chemical Control. Acta Agriculturae Shanghai, 21(2): 1-4.

SKÓRKA P., LENDA M., TRYJANOWSKI P. 2010. Invasive alien goldenrods negatively affect grassland bird communities in Eastern Europe. Biological Conservation, 143: 856-861.

SOWA P., WESOŁOWSKA M., KLUZ M., DŻUGAN M. 2016. Właściwości fizykochemiczne podkarpackich miodów odmianowych [Physicochemical properties of varietal honeys from Podkarpacie Province ] (pp: 257-265). In SZALA M., KROPIWIEC K. Przegląd wybranych zagadnień z zakresu przemysłu spożywczego [Review of selected issues in the field of the food industry]. Wydawnictwo Naukowe TYGIEL sp. z o. o, Lublin. 
SUAREZ-LUQUE S., MATO I., HUIDOBRO J. F., SIMALLOZANO J., SANCHO T. 2002. Rapid determination of minority organic acids in honey by high-performance liquid chromatography. Journal of Chromatography $A$, 955: 207-214.

SUN B. J., TAN J. Z., WAN Z. G., GU F. G., ZHU M. D. 2006. Allelopathic effects of extracts from Solidago canadensis L. against seed germination and seedling growth of some plants. Journal of Environmental Sciences, 18: 304309.

ŠUTOVSKÁ M., CAPEK P., KOCMÁLOVÁ M., FRANOVÁ S., PAWLACZYK I., GANCAEZC R. 2013. Characterization and biological activity of Solidago canadensis complex. International Journal of Biological Macromolecules, 52: 192-197.

SZYMURA M., WOLSKI K. 2006. Zmiany krajobrazu pod wpływem ekspansywnych bylin północnoamerykańskich z rodzaju Solidago L. [Landscape transformation in the influence of expansive North Americans perennial from Solidago L. genus]. Regionalne Studia Ekologiczno-Krajobrazowe, Problemy Ekologii Krajobrazu, 16(1): 451-460.

SZYMURA M. 2012. Ocena zdolności do rozmnażania generatywnego i wegetatywnego nawłoci występujących południowo-zachodniej Polsce [Evaluation of ability for generative and vegetative reproduction of goldenrods occurred in Poland]. Zeszyty Naukowe Uniwersytetu Przyrodniczego we Wrocławiu, Rolnictwo Cl, 585: 103-112.

TOMIYASU T., MATSUO T., MIYAMOTO J., IMURA R., ANAZAWA K., SAKAMOTO H. 2005. Low level mercury uptake by plants from natural environments - mercury distribution in Solidago altissima L. Environmental Sciences, 12: 231-238.

TOKARSKA-GUZIK B., DAJDOK Z., ZAJĄC M., ZAJĄC A., URBISZ A., DANIELEWICZ W. 2012. Rośliny obcego pochodzenia w Polsce ze szczególnym uwzględnieniem gatunków inwazyjnych [Alien species in Poland, with particular emphasis on invasive species]. Generalna Dyrekcja Ochrony Środowiska, Warszawa.

TRYJANOWSKI P., DAJDOK Z., KUJAWA K., KAŁUSKI T., MRÓWCZYŃSKI M. 2011. Zagrożenia różnorodności biologicznej W krajobrazie rolniczym: czy badania wykonywane w Europie Zachodniej pozwalają na poprawną diagnozę w Polsce? [Threats to biodiversity in farmland: are results from Western Europe good solutions for Poland?]. Polish Journal of Agronomy, 7: 113-119.

VANDERHOEVEN S., DASSONVILLE N., CHAPUIS-LARDY L., HAVEZ M., MEERTS P. 2006: Impact of the invasive alien plant Solidago gigantea on primary productivity, plant nutrient content and soil mineral nutrient concentrations. Plant and Soil, 286: 259-268.

WANG C., CHENG H., WEI M., WANG S., WU B., DU D. 2021. Plant height and leaf size: which one is more important in affecting the successful invasion of Solidago canadensis and Conyza canadensis in urban ecosystems?. Urban Forestry \& Urban Greening, 127033.
WEBER E. 2000. Biological flora of Central Europe: Solidago altissima L. Flora, 195: 123-134.

WEBER E., SCHMID B. 1998. Latitudinal population differentiation in two species of Solidago (Asteraceae) introduced into Europe. American Journal of Botany, 85:1110-1121.

WEBER E., SUN S. G., LI B. 2008. Invasive alien plants in China: diversity and ecological insights. Biological Invasions, 10(8): 1411-1429.

XIANG Y. C., FENG T., LIU B. G., CHEN Y. 2010. Growth and accumulation character of heavy metals for Solidago canadensis grown in amended manganese mining tailing. Mineral Engineering Research, 25(1): 63-68.

YANG R., YU G., TANG J., CHEN X. 2008. Effects of metal lead on growth and mycorrhizae of an invasive plant species (Solidago canadensis L.). Journal of Environmental Sciences, 20: 739-744.

YUAN Y., WANG B., ZHANG S., TANG J., TU C., HU S., YONG J. W. H., CHEN X. 2013. Enhanced allelopathy and competitive ability of invasive plant Solidago canadensis in its introduced range. Journal of Plant Ecology, 6: 253263.

ZHANG C. B., WANG J., QIAN B. Y., LI W. H. 2009. Effects of the invader Solidago on soil properties. Applied Soil Ecology, 43: 163-169.

ZHUANG P., SHUW., LIZ., LIAO B., LI J., SHAO J. 2009. Removal of metals by sorghum plants from contaminated land. Journal of Environmental Sciences, 21(10): 1432-1437. 